\author{
지방원으로 전지대두와 아마종실의 첨가가 반추위내 건물과 \\ C18계-불포화지방산의 조성과 소실율에 미치는 영향 \\ 이성훈*최낙진**.맹원재* \\ 건국대학교 축산대학 영양자원학과*, 서울대학교 농생명공학부**
}

\title{
Effects of Full-Fat Soybeans and Linseed as Dietary Fat Sources on In Vitro Ruminal Disappearances of Dry Matter and C18-Unsaturated Fatty Acids and Fatty Acids Profile
}

\author{
S. H. Lee*, N. J. Choi** and W. J. Maeng* \\ Dept. of Nutritional Resources Science, College of Animal Husbandry, Konkuk University*, \\ School of Agricultural Biotechnology, Seoul National University**
}

\begin{abstract}
This study was conducted to investigate the effects of dietary full-fat soybeans and linseed as fat sources on in vitro ruminal disappearances of dry matter and unsaturated fatty acids and fatty acids profile. The full-fat soybeans and linseed were high in linoleic acid (C18:2n-6) and a-linolenic acid (C18:3n-3), respectively. The incubation times were $0,3,6,12,24,48$ and $72 \mathrm{~h}$. After each time of incubation, medium digesta was lyophilized for analyzing its DM and fatty acids contents. DM disappearance was significantly higher in linseed treatment compared to full-fat soybeans treatment on 6 $\mathrm{h}(\mathrm{p}<0.01), 12 \mathrm{~h}(\mathrm{p}<0.05)$ and $24 \mathrm{~h}(\mathrm{p}<0.01)$, but cumulative gas production was not significantly different between both treatments. Stearic acid (C18:0) content in medium digesta was increased in both soybeans and linseed as a result of complete biohydrogenation with increased incubation time and C18:0 and C18:1 contents of full-fat soybeans were significantly higher than those of linseed $(\mathrm{p}<0.05)$. The content of $\mathrm{C} 18: 2$ and $\mathrm{C} 18: 3$ in digesta of each treatment were decreased by biohydrogenation as incubation time was increased. The content of $\mathrm{C} 18: 2$ in full-fat soybeans was significantly higher than that of linseed $(\mathrm{p}<0.05)$ while the content of $\mathrm{C} 18: 3$ in linseed was significantly higher than that of full-fat soybeans $(\mathrm{p}<0.001)$. Net $\mathrm{C} 18: 0$ production was significantly higher in full-fat soybeans $(332.24 \%)$ than linseed $(133.16 \%)$ on $72 \mathrm{~h}$. Disappearance of C18:1 was significantly lower in full-fat soybeans than linseed $(\mathrm{p}<0.05)$, especially full-fat soybeans showed negative $(-)$ values on 3, 6, 12 and $24 \mathrm{~h}$. The disappearance of $\mathrm{C} 18: 3$ was significantly higher in linseed than full-fat soybeans $(\mathrm{p}<0.05)$. The disappearance of $\mathrm{C} 18$-unsaturated fatty acid was significantly higher in linseed than full-fat soybeans. In conclusion, polyunsaturated fatty acid (PUFA) in both full-fat soybeans and linseed were extensively biohydrogenated. In addition, biohydrogenation of PUFA was more completed to C18:0 in full-fat soybeans than linseed, reflecting dietary PUFA composition.
\end{abstract}

(Key words : Full-fat soybeans, Linseed, Gas production, PUFA, Biohydrogenation, Medium digesta)

Corresponding author: W. J. Maeng, Department of Nutritional Resources Science, Konkuk University, Seoul 143-701, Korea. TEL : 02) 450-3697, E-mail : maengwj@konkuk.ac.kr 
I. 서 론

최근 들어, 건강에 대한 관심의 증가로 인하 여 인체에 이로운 식품소재 원이 함유된 기능 성 축산 식품 개발에 대한 연구가 활발히 진행 되고 있다. 임상보고 (Barlow 등, 1990; Sargent 와 Henderson, 1995)에 따르면, 불포화 지방산, 특히 $n-3$ 불포화 지방산이 심혈관계 질병 (cardiovascular disease) 및 동맥경화 (atherosclerosis)를 예방 치료한다고 하였다. 이러한 연 유로, 우유와 쇠고기의 축산 식품 내에 불포화 지방산 함량을 증가시키기 위한 노력을 하고 있으나, 반추동물 소화 생리적으로 반추위 내 에서 불포화 지방산은 수소첨가현상 (biohydrogenation)을 통해 CLA 또는 C18:1 trans지방산 으로 전환되고, 최종적으로 포화지방산인 $\mathrm{C} 18: 0$ 으로 변화한다 (Harfoot과 Hazlewood, 1988). 이 와 같은 현상은 반추위내 서식하는 미생물들에 게 불포화 지방산이 유해한 작용을 하기 때문 에 반추위 조건의 정상화를 위한 일련의 해독 작용이라고 할 수 있다 (Jenkins, 1993). 따라서, 반추위 환경의 저해, 특히 미생물 활동 저하 및 섬유소 분해율 감소 (Palmquist와 Jenkins, 1980)를 피하고 섭취된 불포화 지방산을 biohydrogention 작용으로부터 보호하기 위하여 여 러 가지 방법이 진행되어오고 있다.

예를 들면, calcium soap형성 (Elmeddah 등, 1991), formaldehyde 처리 단백질에 의한 지방 피복 (Hogan 등, 1972; Choi 등, 2000), oilseeds 이용 (Scollan, 2001a; Scollan, 2001b), 고농후사 료사양 (Kucuk 등, 2001) 등의 방법이 수소첨 가 현상감소에 효과적인 것으로 보고되고 있다. Dhiman 등 (1999)은 젖소가 C18:3이 풍부한 목 초를 증가하는 수준으로 섭취시 우유내 $\mathrm{C} 18: 3$ 이 증가한다고 보고하였고, Choi 등 (2000)은 fish oil과 formaldehyde처리 linseed를 육우에게 급여했을 때, 근내에 불포화 지방산 함량이 대 조구 공시축들과 비교하여 증가된 것을 조사하 였고, Scollan 등 (2001b)은 아마종실을 육우사 료에 급여하였을 때 근육내 $\mathrm{C} 18: 3$ 이 유의하게 증가하였고, 또한 $\mathrm{EPA}$ (eicosapentaenoic acid, 20:5n-3)의 합성이 증가하였다고 보고하였다.
따라서, 본 연구에서는 반추동물사료에 흔히 사용되는 불포화지방산원으로 전지대두 $(\mathrm{C} 18$ : $2 n-6)$ 와 아마종실 $(\mathrm{C} 18: 3 n-3)$ 을 사용하여 $i n$ vitro 배양장치에서 배양하였을 때 반추위혼합 미생물에 의한 건물 및 불포화지방산 소실율과 조성에 미치는 영향을 조사하였다.

\section{․ 재료 및 방법}

\section{1. 설험설계}

본 실험은 전지대두와 아마종실의 미생물에 의한 건물과 $\mathrm{C} 18$ 계 불포화지방산 소실율과 지 방산조성을 평가하기 위해 처리구는 전지대두 와 아마종실구 두 처리구로 하고, 배양시간은 $0,3,6,12,24,48,72$ 시간에 걸쳐 Davies 등 (1993)의 방법으로 3 반복, 총 42 개의 serum bottle을 이용하여 완전임의 배치법으로 실시하 였다.

2. 실험사료와 배양액의 준비

실험사료의 배합과 지방산 조성은 table 1에 나타내었고, 전지대두와 아마종실은 전체배합 비의 $18 \%$ (건물기준) 함유토록 하였다. 배합된 사료는 배양을 위해 $-60^{\circ} \mathrm{C}, 48$ 시간동안 동결건 조 후 $1 \mathrm{~mm}$ screen이 장착된 wiley mill로 분쇄 하여 미세입자는 제거하여 배양기질로 사용하 였다. 그리고 아마종실은 배합하기 전 종실의 단백질피막을 crushing하여 미생물의 접근을 용 이하도록 처리하였다. 배양기질은 $100 \mathrm{ml}$ serum bottle에 배양액의 $2 \%$ 에 해당하는 양을 배양에 사용하였다. 배양액은 rumen cannulae가 장착된 Holstein cow로부터 rumen 내용물을 $39^{\circ} \mathrm{C}$ 의 보 온병에 담아 실험실로 운반하여 2겹 gauze를 통해 여과하고, 여과된 rumen fluid는 다시 $1,200 \mathrm{rpm}$ 에서 25 분간 원심분리 후 상층액만 취 하여 centrifuged rumen fluid를 준비하였다. 이 를 medium C (Davies 등, 1993) 배양액에 혼합 하였다.

3. 배양방법 
$39^{\circ} \mathrm{C}$ 로 유지된 배양실에서 배양액을 serum bottle에 automatic pump를 이용해 $60 \mathrm{ml}$ 씩 주입 하고, 혐기조건을 위해 $\mathrm{CO}_{2}$ 를 주입하였으며, rubber stopper와 aluminium crimp로 봉하였다. 배양조건은 $39^{\circ} \mathrm{C}, 100 \mathrm{rpm}$ 으로 교반하면서, 시 간대별로 회수하여 Theodorou 등 (1994)의 방 법으로 가스생성량을 측정하였고, 건물과 지방 산 함량과 조성분석을 위해 digesta 전량을 filter crucible에 여과하여 분석시까지 $-20^{\circ} \mathrm{C}$ 에 서 보관하였다.

\section{4. 분석항목 및 분석방법}

냉동 보관된 digesta는 건물과 지방산분석을 위해 동결건조기 (Labconco, Model 74070; Kansas City, MO)에서 7일간 동결건조 하였다. 동결건조 후 digesta와 실험사료의 순수 건물 함량을 측정하기 위해 다시 일부 시료를 채취 하여 $\mathrm{AOAC}$ 의 방법 (1990)에 따라 $105^{\circ} \mathrm{C}$ dry oven에 24시간 건조 후 무게차이에 의해 정량 하였다. 각 배양시간마다 배양병의 가스 측정 은 Theodorou 등 (1994)의 방법에 따라 pressure transducer apparatus (IGER, UK)를 이용하여 압 력 $(\mathrm{psi})$ 과 부피 $(\mathrm{ml})$ 를 측정하였고, 0 시간의 가 스생성량은 혐기상태를 유지시키기 위해 주입 하는 $\mathrm{CO}_{2}$ 에 의해 과대 평가되므로 배양개시 후 syringe를 이용하여 배양병내의 모든 가스를 제거하여 압력이 0 (zero)으로 되게 하였다. 실 험사료와 digesta의 장쇄지방산 (long chain fatty acids) 분석은 Sukhija와 Palmquist (1988)의 방 법에 따라 동결건조시료 $200 \mathrm{mg}$ 을 취하여 toluene으로 지방산을 추출한 후, 추출된 지방 산을 다시 FAME (fatty acid methyl ester)으로 유도하기 위해 $5 \%$ methanolic $\mathrm{HCl}$ 을 첨가하여 $70^{\circ} \mathrm{C}$ heating block에서 2시간동안 가열하여 methylation을 실시하였다. FAME의 toluene solvent에 함유되어 있는 수분 및 색소를 포함 한 불순물을 제거하기 위해 activated charcoal 과 anhydrous sodium sulphate를 첨가하여 1,500 $\mathrm{rpm}$ 에서 원심분리 후 상층액을 취하여 gas chromatography (UNICAM 610 series model, $\mathrm{UK})$ 를 이용하여 분석하였다. 지방산분석에 사
용된 column은 fused silica capillary column $(30 \mathrm{~m} \times 0.32 \mathrm{~mm}, 0.5 \mu \mathrm{m}$ film thickness, HP Innowax)이었고, detector는 FID (flame ionization detector)이었다. Inlet과 detector 온도는 각각 $200^{\circ} \mathrm{C}$ 와 $250^{\circ} \mathrm{C}$ 이었으며, column oven 온도는 초기 3 분 동안 $60^{\circ} \mathrm{C}$ 에서 시작하여 $230^{\circ} \mathrm{C}$ 까지 올라가는데 분당 $20^{\circ} \mathrm{C}$ 상승하도록 프로그램 하 였다. Carrier gas로서 $\mathrm{N}_{2}$ 를 사용하여 flow rate 는 분당 $20 \mathrm{ml}$ 가 되도록 하고, split ratio는 $100: 1$ 이었다. 각 지방산 peak는 이미 알고 있는 external standard (Mixture ME61, Greyhound chromatography chemicals, UK)와 area 값을 비 교하여 정량하였고, 본 실험에 이용된 $\mathrm{GC}$ column은 C18:1지방산의 위치적, 입체적 이성 체를 각각 분리해내지 못하기 때문에 $\mathrm{C} 18: 1$ 은 이성체의 합으로 나타내었다.

건물소실율은 배양전 기질의 건물량과 배양 후 기질의 건물량간의 차이에 의해 구하였으 며, net C18:0 생산량과 $\mathrm{C} 18$ 계 불포화지방산소 실율은 Van Nevel과 Demeyer (1996)의 방법에 따라 다음과 같이 계산하였다.

Net $\mathrm{C} 18: 0$ production $(\%)=$ (배양후 digesta내 C18:0 함량 배양전 사료내 $\mathrm{C} 18: 0)$

배양전 사료내 $\mathrm{C} 18: 0$ 함량 $\times 100$

$\mathrm{C} 18$ 계 불포화지방산 소실율 $(\%)=$ (배양전 사료내 $\mathrm{C} 18$ 계 불포화지방산 함량-

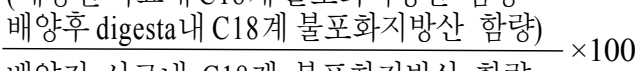
배양전 사료내 $\mathrm{C} 18$ 계 불포화지방산 함량

\section{5. 통계 분석}

본 실험에서 얻어진 모든 결과는 SAS package program (2000, release. 8.1 ver.)을 이용하 여 분석하였고, 건물소실율 및 gas 생성량 그리 고 지방산소실율은 t-test를 이용하여 $5 \%$ 수준 에서 두 처리구간의 평균을 비교검정하였고, 가스생성량과 압력간의 상관계수 및 유의성은 SAS program의 Pearson 상관계수절차를 이용하 여 도출하였다. 


\section{III. 결과 및 고찰}

본 연구는 반추동물의 지방사료원으로 흔히 사용되는 아마종실과 전지대두의 반추위내 건 물소실율과 $\mathrm{C} 18$ 계 지방산소실율을 조사하기 위해 실시한 실험으로, 실험사료의 화학적조성 은 table 1에 나타내었다. 전지대두와 아마종실 의 총 지방산 함량은 건물 $\mathrm{kg}$ 당 각각 50.73 과 $47.46 \mathrm{~g}$ 으로 전지대두가 지방산 함량이 다소 높 았다. 그리고 전지대두는 $\mathrm{C} 18: 2$ 함량이 $24.05 \mathrm{~g}$ 으로 많았고, 이에 반해 아마종실은 $\mathrm{C} 18: 3$ 이 $20.51 \mathrm{~g}$ 으로 다른 지방산 함량보다 높아 두 처 리구간에 조성에 있어 대조를 이루었다.

\section{1. 건물소실율과 가스생성량}

전지대두와 아마종실이 반추위내 건물소실율 과 가스생성량에 미치는 영향은 table 2에 나타 내었다. 전지대두와 아마종실은 배양 3 시간까 지는 건물소실율에 영향을 미치지 않았으나, 배양 6시간 이후부터는 아마종실이 전지대두보 다 유의한 증가를 나타내었다 $(\mathrm{p}<0.01)$. 하지만, 배양 48시간 이후부터는 두 처리구간에 유의차 가 나타나지 않았다 $(\mathrm{p}>0.05)$. 한편 가스생성량 은 건물소실율과 비슷한 양상을 나타내어 아마 종실이 전지대두보다 가스를 보다 많이 생성하 나 두 처리구간에 유의한 차이는 나타나지 않 았다 $(\mathrm{p}>0.05)$. 그리고 Fig. 1은 가스발생장치 (IGER, UK)의 압력 (psi)과 가스생성량 $(\mathrm{ml})$ 간 의 상관관계 및 회귀식을 나타낸 것으로서 그 림에서 보는 바와 같이 두 변수간에 유의한 상 관도를 나타내었고 $(\mathrm{p}<0.0001)$, 본 장치를 통한 기질의 가스생성량 및 발효정도를 평가하는데 안정적이었다.

대두와 종실류는 일반적으로 반추동물사료에 불포화지방산원으로서 흔히 사용되나 (NRC, 2001), 과도한 양을 반추동물사료에 첨가시 반 추위내 미생물의 환경을 저하시켜 섭취하는 사 료의 분해를 감소시킨다(Doreau와 Ferlay, 1994). 본 연구의 결과는 table 1 에 총지방산 함량이 나타나있듯이, 전지대두가 아마종실보 다 지방산 함량이 높아 반추위내 미생물성장환
Table 1. Feed ingredients and fatty acids composition of experimental diets

\begin{tabular}{|c|c|c|}
\hline \multirow[b]{2}{*}{ Item } & \multicolumn{2}{|c|}{ Dietary fat sources } \\
\hline & $\begin{array}{c}\text { Full-fat } \\
\text { soybeans }\end{array}$ & Linseed \\
\hline \multicolumn{3}{|c|}{ Ingredients, \% of DM } \\
\hline Wheat & 49.00 & 49.00 \\
\hline Sugarbeet pulp & 8.00 & 8.00 \\
\hline Molasses, sugarcane & 5.00 & 5.00 \\
\hline Full-fat soybeans & 18.00 & - \\
\hline Crushed linseed & - & 9.60 \\
\hline Linseed meal & - & 8.40 \\
\hline Grass silage & 10.00 & 10.00 \\
\hline Wheat straw & 10.00 & 10.00 \\
\hline \multicolumn{3}{|c|}{ Fatty $_{\text {acids }}{ }^{1)}, g / k g$ DM } \\
\hline 14:0 myristic & 0.13 & 0.26 \\
\hline 14:1 myristoleic & 0.04 & $\mathrm{ND}^{3)}$ \\
\hline 16:0 palmitic & 8.61 & 5.57 \\
\hline 16:1 palmitoleic & 0.10 & 0.17 \\
\hline 18:0 stearic & 2.16 & 2.13 \\
\hline $18: 1^{2)}$ & 11.49 & 9.34 \\
\hline 18:2n-6 linoleic & 24.05 & 9.19 \\
\hline $18: 3 n-3$ a-linolenic & 3.27 & 20.51 \\
\hline Total fatty acids & 50.73 & 47.46 \\
\hline
\end{tabular}

\footnotetext{
1) expressed as number of carbons:number of double bonds;

2) sum of oleic acid (C18:1, cis-9) and positional or geometric isomers;

3) not detectable
}

경에 다소 영향을 미친 것으로 판단되며, 이에 아마종실이 전지대두보다 소실율이 증가한 것 으로 사료된다. Broderick 등 (1988)은 어분, 대 두박, 아마종실박, 해바라기박, 채종박, 땅콩박, 육골분을 in vitro 발효소화실험을 실시하였을 때 이들 각각의 분해율은 $55,79,84,59,75$, $54,58 \%$ 를 나타내어, 아마종실의 단백질부분이 대두 단백질보다 잘 분해되어 단백질부분의 분 해 용이함을 나타내었다. 그리고, Scollan 등 (2001a)의 연구에서는 지방원인 아마종실, 어유, 아마종실/어유혼합구가 보호지방형태인 Megalac ${ }^{\circledR}$ 
Table 2. Effect of dietary fat sources on DM disappearance (\%) and gas production (ml) in vitro

\begin{tabular}{|c|c|c|c|c|}
\hline \multirow{2}{*}{ Incubation time (h) } & \multicolumn{2}{|c|}{ Dietary fat sources } & \multirow{2}{*}{ s.e.d. ${ }^{1)}$} & \multirow{2}{*}{$\mathrm{p}^{<^{2)}}$} \\
\hline & Full-fat soybeans & Linseed & & \\
\hline \multicolumn{5}{|c|}{ DM disappearance (\%) } \\
\hline 0 & $24.33 \pm 3.53$ & $28.03 \pm 1.02$ & 2.9409 & 0.4776 \\
\hline 3 & $26.94 \pm 1.82$ & $28.85 \pm 1.03$ & 1.9278 & 0.4031 \\
\hline 6 & $37.16 \pm 1.40$ & $46.71 \pm 2.12$ & 2.4587 & 0.0067 \\
\hline 12 & $48.63 \pm 2.24$ & $57.39 \pm 0.52$ & 2.1008 & 0.0157 \\
\hline 24 & $57.46 \pm 0.51$ & $60.69 \pm 0.72$ & 0.8587 & 0.0071 \\
\hline 48 & $65.01 \pm 1.95$ & $67.24 \pm 2.90$ & 3.3867 & 0.5438 \\
\hline 72 & $70.93 \pm 1.76$ & $74.61 \pm 1.62$ & 2.8857 & 0.1561 \\
\hline \multicolumn{5}{|c|}{ Cumulative gas production $(\mathrm{m} \ell)^{3)}$} \\
\hline 3 & $22.00 \pm 2.65$ & $20.33 \pm 5.17$ & 5.8119 & 0.7885 \\
\hline 6 & $51.33 \pm 6.23$ & $63.33 \pm 6.77$ & 9.1999 & 0.2621 \\
\hline 12 & $65.67 \pm 7.99$ & $83.67 \pm 5.90$ & 9.9317 & 0.1441 \\
\hline 24 & $131.00 \pm 8.52$ & $148.33 \pm 6.23$ & 10.553 & 0.1758 \\
\hline 48 & $179.50 \pm 8.37$ & $192.33 \pm 6.77$ & 10.764 & 0.2991 \\
\hline 72 & $199.83 \pm 8.08$ & $210.33 \pm 6.82$ & 10.578 & 0.3771 \\
\hline
\end{tabular}

1) standard error of difference; ${ }^{2)}$ Values significantly differ $(\mathrm{p}<0.05)$;

3) After incubation initiation, gas produced at the time of $0 \mathrm{~h}$ was removed to avoid its overestimation due to injected $\mathrm{CO}_{2}$ to keep anaerobic condition prior to incubation.

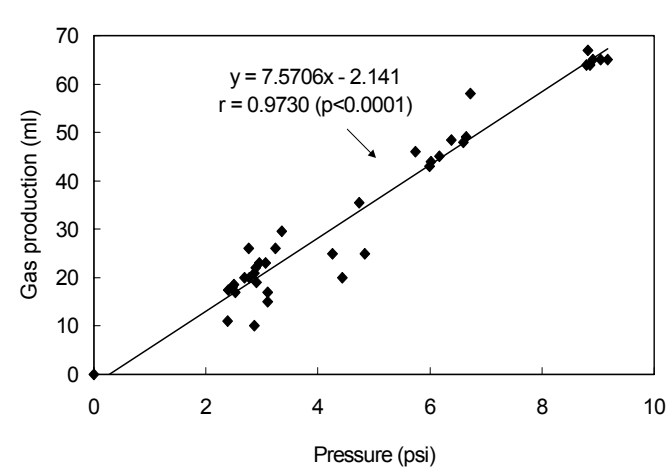

Fig. 1. The linear regression and correlationship between pressure (psi) and gas production (ml) in pressure transducer apparatus (The number of observed values was 37 ).

첨가구보다 총 휘발성 지방산 함량이 유의하게 증가하여 반추위내 발효에 원활한 효과를 시사
한 바 있고, 하지만 일반적으로 지방원의 첨가 는 반추위내 유기물의 소화를 감소시킨다고 알 려져 있다(Palmquist와 Jenkins, 1980; Ikwuegbu 와 Sutton, 1982 ; Jenkins, 1993).

\section{Digesta내 C18계 지방산 조성}

전지대두와 아마종실이 반추위 digesta의 $\mathrm{C} 18$ 계 지방산 조성에 미치는 영향은 table 3 에 나 타내었다. C18계 지방산은 digesta DM $\mathrm{kg}$ 당 $\mathrm{g}$ 으로 나타내었고, stearic acid (C18:0)는 배양시 간이 증가함에 따라 전지대두와 아마종실 공히 증가하였다. 그리고, $\mathrm{C} 18: 0$ 에 대하여 전지대두 는 전체배양시간 평균 $16.59 \mathrm{~g} / \mathrm{kg} \mathrm{DM}$ 으로 아 마종실의 $12.68 \mathrm{~g} / \mathrm{kg}$ DM보다 유의하게 높았다 $(\mathrm{p}<0.05)$. Digesta내 $\mathrm{C} 18: 0$ 의 배양시간에 따른 증가는 사료 $\mathrm{C} 18$ 계 불포화지방산에 대한 반추 
Table 3. Effects of dietary fat sources on C18-fatty acids profile of digesta depending upon the time after incubation in vitro

\begin{tabular}{|c|c|c|c|c|c|c|c|c|}
\hline \multirow{3}{*}{ Fatty acids } & \multicolumn{8}{|c|}{ Incubation time $(\mathrm{h})$} \\
\hline & \multicolumn{2}{|r|}{0} & \multicolumn{2}{|c|}{3} & \multicolumn{3}{|c|}{6} & \multirow{2}{*}{$\begin{array}{c}12 \\
\mathrm{~S}\end{array}$} \\
\hline & $\mathrm{S}^{1)}$ & $\mathrm{L}^{2)}$ & $\mathrm{S}$ & $\mathrm{L}$ & $\mathrm{S}$ & & $\mathrm{L}$ & \\
\hline & & C18 & 8-fatty acid & profile in di & igesta $(\mathrm{g} / \mathrm{k}$ & $D M$ & & \\
\hline \multirow[t]{2}{*}{ C18:0 } & $4.27^{4)}$ & $3.90^{*}$ & 6.42 & 6.25 & 9.12 & & 8.11 & 17.19 \\
\hline & \pm 0.07 & \pm 0.06 & \pm 0.08 & \pm 0.29 & \pm 0.02 & \pm & 0.66 & 0.93 \\
\hline \multirow[t]{2}{*}{$\mathrm{C} 18: 1^{3)}$} & 13.06 & $10.24 * * *$ & 15.61 & $12.05^{* * *}$ & 20.70 & & $15.75^{* * *}$ & 28.68 \\
\hline & \pm 0.11 & \pm 0.13 & \pm 0.12 & \pm 0.26 & \pm 0.30 & \pm & 0.51 & 0.56 \\
\hline \multirow[t]{2}{*}{$\mathrm{C} 18: 2$} & 25.14 & $9.52 * * *$ & 22.18 & $9.07 * * *$ & 18.07 & & $7.96 * * *$ & 13.58 \\
\hline & \pm 0.30 & \pm 0.09 & \pm 0.24 & \pm 0.14 & \pm 0.42 & \pm & 0.01 & 0.89 \\
\hline \multirow[t]{2}{*}{$\mathrm{C} 18: 3$} & 3.25 & $18.86^{* * *}$ & 2.71 & $17.00 * * *$ & 2.13 & & $13.23 * * *$ & 1.58 \\
\hline & \pm 0.03 & \pm 0.31 & \pm 0.04 & \pm 0.27 & \pm 0.02 & \pm & 0.08 & 0.10 \\
\hline
\end{tabular}

\begin{tabular}{|c|c|c|c|c|c|c|c|}
\hline \multirow{3}{*}{ Fatty acids } & \multicolumn{7}{|c|}{ Incubation time $(\mathrm{h})$} \\
\hline & 12 & & & & & & \\
\hline & $\mathrm{L}$ & $\mathrm{S}$ & $\mathrm{L}$ & $\mathrm{S}$ & $\mathrm{L}$ & $\mathrm{S}$ & $\mathrm{L}$ \\
\hline
\end{tabular}

\section{C18-fatty acids profile in digesta $(\mathrm{g} / \mathrm{kg} \mathrm{DM})$}

\begin{tabular}{lccccccc}
$\mathrm{C} 18: 0$ & $10.32^{* *}$ & 22.32 & $17.31^{* * *}$ & 25.92 & 23.45 & 30.91 & $19.44^{*}$ \\
& \pm 0.24 & \pm 0.82 & \pm 0.37 & \pm 0.54 & \pm 3.44 & \pm 3.71 & \pm 1.45 \\
$\mathrm{C} 18: 1^{3)}$ & $19.67^{* * *}$ & 28.97 & $21.02^{* * *}$ & 25.46 & $18.91^{* *}$ & 23.79 & $15.84^{*}$ \\
& \pm 0.25 & \pm 0.35 & \pm 0.19 & \pm 0.69 & \pm 1.40 & \pm 2.21 & \pm 0.63 \\
$\mathrm{C} 18: 2$ & $6.59^{* *}$ & 10.94 & $4.73^{* * *}$ & 6.66 & $3.38^{* * *}$ & 4.82 & $2.56^{*}$ \\
& \pm 0.11 & \pm 0.30 & \pm 0.06 & \pm 0.33 & \pm 0.31 & \pm 0.68 & \pm 0.18 \\
$\mathrm{C} 18: 3$ & $9.42^{* * *}$ & 1.30 & $4.93^{* * *}$ & 0.92 & $3.36^{* * *}$ & 0.71 & $2.61^{* * *}$ \\
& \pm 0.03 & \pm 0.01 & \pm 0.16 & \pm 0.05 & \pm 0.14 & \pm 0.08 & \pm 0.16 \\
\hline
\end{tabular}

1) full-fat soybeans; ${ }^{2)}$ linseed; ${ }^{3)}$ sum of oleic acid (C18:1, cis-9) and positional or geometric isomers;

4) all values were expressed as mean \pm standard error.

$*, * *$ and $* * *$ are significantly different at the levels of 5,1 and $0.1 \%$, respectively, between full-fat soybeans and linseed in the same incubation time.

위미생물에 의한 biohydrogenation의 최종결과 산물이며 (Palmquist와 Jenkins, 1980), 불포화지 방산 급여로 인한 우유나 고기내 포화지방산의 증가를 반영하는 결과이다. Clinquart 등 (1991)
의 연구결과에 의하면, 대두유와 아마종실을 급여한 비육우에서 신장내 C18:0 지방산은 아 마종실보다 대두유가 유의하게 증가하였다고 보고하여 본 실험결과와 일치하였으며, 지방사 
료원은 반추위 미생물대사에 유의한 영향을 나 타낸다. 한편 Scollan (2001b) 등은 사료 중 $n-3$ 지방산 즉, $\mathrm{C} 18: 3 n-3$ 이 풍부한 아마종실이나 $\mathrm{C} 20: 5(n-3, \mathrm{EPA})$ 와 $\mathrm{C} 22: 6$ (n-3, DHA)이 풍부 한 어유의 급여는 근육내 $\mathrm{C} 18: 0$ 이 감소한다고 하였다. 그리고, Kelly 등 (1998b)은 C18:2가 풍 부한 해바라기유는 우유내 stearic acid와 CLA 함량을 아마종실보다 유의하게 증가시켰다고 보고하였다. 본 연구에서 $\mathrm{C} 18: 1$ 의 함량은 이전 에 언급했듯이 이성질체의 분리가 되지 않는 지방산분석 column으로 C18:1n-9 뿐만 아니라 위치적 기하학적 이성질체를 포함한 수치이고, 분리되지 않은 trans지방산까지 포함한다. C18:1 함량은 배양시간이 증가할수록 $\mathrm{C} 18: 0$ 과 마찬가 지로 증가하였고, 특히 전지대두가 아마종실구 보다 유의하게 증가하였다 $(\mathrm{p}<0.05) . \mathrm{C} 18: 2 n-6$ 이 풍부한 전지대두구가 아마종실보다 $\mathrm{C} 18: 1$ 이 증 가한 것은 이성질체의 영향이 큰 것으로 판단 되며, 이전의 연구에서 사료 중 $\mathrm{C} 18: 2$ 의 급여 는 반추위내 불완전한 수소첨가현상으로 인한 trans $\mathrm{C} 18: 1$ 뿐만 아니라, 우유 중 CLA 함량을 증가시킨다고 보고하였다. McGuire 등 (1996)과 Griinari 등 (1996)은 C18:2가 풍부한 옥수수유 의 첨가는 사료 중 $\mathrm{C} 18: 2$ 함량과 비례하여 우 유 중 CLA 및 trans 지방산이 증가한다고 보 고하였으며 본 실험에서도 아마종실보다는 C18:2가 풍부한 전지대두가 trans 및 CLA 지방 산을 더 생산하여 이와 같은 결과를 나타낸 것 으로 사료된다. Digesta내 C18:2와 C18:3의 함 량은 배양시간이 증가함에 따라 감소하였다. 이는 사료 중 불포화 지방산 특히 $\mathrm{C} 18: 2$ 와 $\mathrm{C} 18: 3$ 이 반추위내 미생물에 의해 $\mathrm{C} 18: 0$ 혹은 trans 형태의 지방산으로 변형 (transformation)되 어 그 함량이 감소한 것으로 판단된다. 불포화 지방산은 인체건강에 유익한 효과가 있고, 일 반적으로 반추동물사료내 불포화지방산원으로 oilseed를 급여하여 우유나 고기내 이들 지방산 함량을 증가시킨다 (Petit, 2002). 본 실험에서도 물론 반추위내 불포화지방산의 체류시간이 증 가함에 따라 이들 지방산의 함량은 감소하나, 상대적인 비교를 하였을 때 C18:2가 풍부한 사 료인 전지대두가 아마종실에 비하여 digesta내
에서 $\mathrm{C} 18: 2$ 가 유의하게 증가하였고 $(\mathrm{p}<0.05)$, 이와 반대로 $\mathrm{C} 18: 3$ 이 풍부한 아마종실은 전지 대두에 비하여 digesta내 C18:3이 유의하게 증 가하여 축산물내 이들 지방산 증가의 잠재성을 나타내주는 결과이다 $(\mathrm{p}<0.001)$. Petit (2002)에 의하면, 아마종실의 급여는 전지대두 및 $\mathrm{Megalac}^{\circledR}$ 에 비하여 혈중 $\mathrm{C} 18: 3$ 의 비율을 약 3 배정도 유의하게 증가시켰고, 전지대두는 혈중 $\mathrm{C} 18: 2$ 비율이 유의하게 증가하였다고 보고하였 다. Dhiman 등 (1999)과 Kelly 등 (1998a)은 목 초의 주요지방산인 $\mathrm{C} 18: 3$ 의 섭취량이 증가함에 따라 우유내 $\mathrm{C} 18: 3$ 이 증가한다고 보고하였다. 이에 따라 우유나 고기의 지방산은 사료지방산 에 따라 유의한 영향을 받으며, 각 지방산 섭 취량이 증가함에 따라 하부장관으로 이행하는 량이 증가하게 되고, 결과적으로 체내에서 대 사되는 $n-3$ 또는 $n-6$ 지방산이 증가하여 우유나 고기 중에 그 함량이 존재한다고 설명할 수 있 다.

\section{C18:0 생산량과 C18계 불포화지방산 소 실율}

전지대두와 아마종실이 $\mathrm{C} 18$ 계 불포화지방산 의 반추위내 미생물에 의한 최종대사산물인 순 수 $\mathrm{C} 18: 0$ 생산량(\%)과 $\mathrm{C} 18$ 계 불포화지방산 소 실율에 미치는 영향은 table 4에 나타내었다. 순수 $\mathrm{C} 18: 0$ 생산량(\%)은 $\mathrm{C} 18: 2 n-6$ 함량이 풍부 한 전지대두가 배양종료 후 $332.24 \%$ 로 아마 종실의 $133.16 \%$ 보다 유의하게 증가하였다 $(\mathrm{p}<$ 0.05). C18:0의 생산량은 불포화지방산의 complete biohydrogenation의 결과이고, $\mathrm{C} 18: 2$ 가 풍 부한 전지대두가 아마종실보다 C18:0을 유의하 게 증가시켰다. C18:0 생산량은 배양 3시간이 후부터 급격히 증가하여 배양 24시간에 최고수 준에 이르렀다. 반추위내 $\mathrm{C} 18$ 계 불포화지방산 의 pathway는 Harfoot과 Hazlewood (1988)에 의 해 review된 바 있고, 불포화지방산의 biohydrogenation pathway는 미생물의 lipase에 의한 지 방산과 glycerol의 ester 결합을 가수분해하는 지 방분해과정(lipolysis)과 가수분해된 nonesterified fatty acid (NEFA)의 이중결합위치에 반추위미 
Table 4. Effect of dietary fat sources on net C18:0 production and C18-unsaturated fatty acids disappearance (\%) in vitro (Calculation based on Van Nevel and Demeyer, 1996)

\begin{tabular}{|c|c|c|c|c|}
\hline \multirow{2}{*}{ Incubation time (h) } & \multicolumn{2}{|c|}{ Dietary fat sources } & \multirow{2}{*}{ s.e.d. ${ }^{1)}$} & \multirow{2}{*}{$\mathrm{p}<^{2)}$} \\
\hline & Full-fat soybeans & Linseed & & \\
\hline \multicolumn{5}{|c|}{ Net C18:0 production (\%) } \\
\hline 0 & $56.52 \pm 10.93$ & $31.57 \pm 1.38$ & 11.0190 & 0.0862 \\
\hline 3 & $125.00 \pm 8.56$ & $108.73 \pm 11.19$ & 14.0880 & 0.2748 \\
\hline 6 & $164.89 \pm 6.31$ & $103.78 \pm 21.85$ & 20.9230 & 0.0466 \\
\hline 12 & $310.54 \pm 35.90$ & $106.20 \pm 5.62$ & 32.9960 & 0.0043 \\
\hline 24 & $339.15 \pm 18.68$ & $219.27 \pm 10.66$ & 22.7830 & 0.0006 \\
\hline 48 & $319.70 \pm 26.09$ & $271.30 \pm 73.13$ & 72.0360 & 0.5603 \\
\hline 72 & $332.24 \pm 63.81$ & $133.16 \pm 28.70$ & 82.9310 & 0.0258 \\
\hline \multicolumn{5}{|c|}{ C18:13) disappearance (\%) } \\
\hline 0 & $9.90 \pm 4.88$ & $21.12 \pm 2.15$ & 5.3306 & 0.1031 \\
\hline 3 & $-3.05 \pm 3.52$ & $8.14 \pm 2.79$ & 4.4880 & 0.0318 \\
\hline 6 & $-13.13 \pm 2.21$ & $9.95 \pm 5.63$ & 5.6327 & 0.0114 \\
\hline 12 & $-28.47 \pm 7.38$ & $10.27 \pm 1.60$ & 6.8966 & 0.0054 \\
\hline 24 & $-7.24 \pm 1.04$ & $11.56 \pm 1.64$ & 1.8789 & $<0.0001$ \\
\hline 48 & $22.28 \pm 5.20$ & $32.66 \pm 9.44$ & 10.2750 & 0.3706 \\
\hline 72 & $36.11 \pm 10.54$ & $56.79 \pm 4.01$ & 13.5510 & 0.1138 \\
\hline \multicolumn{5}{|c|}{ C18:2 n-6 disappearance (\%) } \\
\hline 0 & $17.17 \pm 4.28$ & $25.39 \pm 1.76$ & 4.6230 & 0.1500 \\
\hline 3 & $30.23 \pm 1.37$ & $29.69 \pm 1.80$ & 2.2638 & 0.8163 \\
\hline 6 & $52.72 \pm 1.93$ & $53.86 \pm 1.81$ & 2.6843 & 0.6764 \\
\hline 12 & $71.20 \pm 1.43$ & $69.41 \pm 0.66$ & 1.4794 & 0.3013 \\
\hline 24 & $80.68 \pm 0.39$ & $79.75 \pm 0.38$ & 0.5534 & 0.1239 \\
\hline 48 & $90.27 \pm 0.79$ & $87.73 \pm 1.88$ & 1.9072 & 0.2649 \\
\hline 72 & $93.74 \pm 1.31$ & $92.87 \pm 0.86$ & 1.7724 & 0.5926 \\
\hline \multicolumn{5}{|c|}{ C18:3 n-3 disappearance (\%) } \\
\hline 0 & $21.46 \pm 3.63$ & $33.78 \pm 1.98$ & 4.1371 & 0.0408 \\
\hline 3 & $37.27 \pm 1.12$ & $40.98 \pm 1.55$ & 1.9109 & 0.0810 \\
\hline 6 & $59.00 \pm 1.14$ & $65.62 \pm 1.41$ & 1.7926 & 0.0063 \\
\hline 12 & $75.33 \pm 1.14$ & $80.42 \pm 0.26$ & 1.0647 & 0.0096 \\
\hline 24 & $83.10 \pm 0.24$ & $90.56 \pm 0.27$ & 0.3596 & $<0.0001$ \\
\hline 48 & $90.16 \pm 0.80$ & $94.58 \pm 0.63$ & 1.0550 & 0.0020 \\
\hline 72 & $93.26 \pm 1.26$ & $96.75 \pm 0.36$ & 1.5957 & 0.0383 \\
\hline \multicolumn{5}{|c|}{ Unsaturated $\mathrm{C}^{4} \mathrm{~B}^{4)}$ disappearance (\%) } \\
\hline 0 & $15.38 \pm 4.40$ & $28.77 \pm 1.96$ & 4.8165 & 0.0498 \\
\hline 3 & $20.97 \pm 1.94$ & $30.46 \pm 1.89$ & 2.7052 & 0.0057 \\
\hline 6 & $33.76 \pm 1.76$ & $49.53 \pm 2.43$ & 2.9335 & 0.0009 \\
\hline 12 & $42.04 \pm 2.21$ & $61.04 \pm 0.64$ & 2.1133 & 0.0006 \\
\hline 24 & $54.86 \pm 0.29$ & $69.11 \pm 0.53$ & 0.5737 & $<0.0001$ \\
\hline 48 & $70.13 \pm 2.08$ & $78.15 \pm 3.03$ & 3.5740 & 0.0637 \\
\hline 72 & $76.64 \pm 4.02$ & $86.27 \pm 1.35$ & 5.1355 & 0.0631 \\
\hline
\end{tabular}

1) standard error of difference; ${ }^{2)}$ values significantly differ $(\mathrm{p}<0.05)$; ${ }^{3)}$ sum of oleic acid $(\mathrm{C} 18: 1$, cis-9) and positional or geometric isomers; ${ }^{4)}$ sum of $\mathrm{C} 18: 1, \mathrm{C} 18: 2$ and $\mathrm{C} 18: 3$. 
생물이 수소를 첨가하는 수소첨가현상 (biohydrogenation)의 일련의 과정으로 진행된다. $\mathrm{C} 18: 2 n-6$ 과 $\mathrm{C} 18: 3 n-3$ 은 isomerase와 reductase의 효소에 의해 최종적으로 $\mathrm{C} 18: 0$ 을 생산한다. $\mathrm{C} 18: 2$ 와 $\mathrm{C} 18: 3$ 의 $\mathrm{C} 18: 0$ 로의 complete biohydrogenation은 이중결합수가 적은 $\mathrm{C} 18: 2$ 가 $\mathrm{C} 18: 3$ 보 다 pathway 단축으로 인하여, 전지대두가 아마 종실보다 complete biohydrogenation이 증가한 것으로 사료된다. 한편, Mosley 등 (2002)은 C18:1인 oleic acid (cis-9)를 반추위 미생물에 적용하였을 때 C18:0, C18:1n-9 뿐만 아니라 여 러 종류의 trans $\mathrm{C} 18: 1$ 이 발견되었다 하여, 직 접적인 $\mathrm{C} 18: 0$ 으로의 전환보다는 몇 가지 이성 체가 생성되어 $\mathrm{C} 18: 2$ 와 $\mathrm{C} 18: 3$ 의 유사한 경로를 거치는 것으로 나타났다.

C18:1 소실율은 전지대두가 아마종실보다 유 의하게 낮았고 $(\mathrm{p}<0.05)$, 특히 배양 $3,6,12,24$ 시간에서 전지대두 처리구가 음 $(-)$ 값을 나타 내었다. 본 실험에서 사용된 gas chromatography column은 $\mathrm{C} 18: 1$ 지방산을 $\mathrm{C} 18: 1 n-9$ 외 에 위치적 기하학적 이성질체를 분리하지 못하 고 이들 지방산이 모두 $\mathrm{C} 18: 1$ 로 합쳐졌으므로 전지대두의 (-)값은 전지대두에 풍부한 $\mathrm{C} 18: 2$ 가 반추위 미생물에 의한 불완전한 수소첨가현 상으로 인한 trans 지방산과 conjugated 지방산 이 많이 생성되어 전지대두의 $\mathrm{C} 18: 1$ 소실율이 과소평가된 것으로 사료된다. Kelly 등 (1998b) 은 착유우에게 $\mathrm{C} 18: 1 n$-9가 풍부한 땅콩유 (peanut oil), $\mathrm{C} 18: 2$ 가 풍부한 해바라기유 (sunflower oil) 그리고 $\mathrm{C} 18: 3$ 이 풍부한 아마종 실유 (linseed oil)를 사료 건물기준 $5.3 \%$ 를 첨 가했을 때 해바라기유가 conjugated fatty acid인 CLA가 우유 중에 다른 처리구보다 유의하게 증가하였다고 보고하였고, 특히 불포화지방산 중 $\mathrm{C} 18: 2$ 가 $\mathrm{CLA}$ 합성에 효과적인 것으로 나타 났다. 또한 Madron 등 (2002)은 전지대두의 extruding 가공처리가 근간 (intermuscular), 근내 (intramuscular) 지방내 CLA가 증가함을 보고하 여 불포화지방산원과 가공처리에 따라 반추위 미생물에 의한 지방대사가 달라질 수 있음을 보고하여 본 실험결과를 뒷받침 해주었다. C18:2의 소실율은 반추위 지방산 biohydrogenation rate와 유사한 개념으로서 전지대두와 아마종실 간에 유의한 차이가 나타나지 않았다 $(\mathrm{p}>0.05)$. $\mathrm{Wu}$ 등 (1991)은 야자지방산의 Ca soap 형태인 $\mathrm{Megalac}^{\circledR}$ 을 각각 $3 \%$ 와 $6 \%$ 첨가와 동식물성 혼합유지(animal-vegetable blend)를 각각 3\%와 $6 \%$ 첨가하는 실험에서 $\mathrm{C} 18: 2$ 의 biohydrogenation rate는 $\mathrm{Ca}$ soap 형태가 동식물성 혼합유지 보다 유의하게 감소하였으나, 동식물성 혼합유 지의 증가 급여에 따른 C18:2의 biohydrogenation rate에는 유의한 차이가 나타나지 않았다 고 보고하였다. 본 실험에서도 $\mathrm{C} 18: 2$ 가 풍부한 전지대두는 아마종실과 비교하여 $\mathrm{C} 18: 2$ 의 소실 율에 유의한 영향을 받지 않아 일치된 결과를 나타내었다. 그리고 $\mathrm{C} 18: 2$ 의 소실율은 배양 시 간이 증가함에 따라 증가하였고, 배양 72 시간 에서 두 처리구 평균 $93.31 \%$ 로 반추위내 미생 물에 의해 광범위한 biohydrogenation이 일어나 는 것으로 평가되었으며, Enjalbert 등 (1994)의 연구에서 대두유 첨가구의 C18:2 biohydrogenation rate가 $94.3 \%$ 로 높아 본 연구와 유사한 수치의 결과를 나타내었다.

$\mathrm{C} 18: 3$ 소실율은 $\mathrm{C} 18: 2$ 의 소실율과 마찬가지 로 배양시간이 증가함에 따라 증가하였으며, 특히 아마종실이 전지대두에 비하여 배양 6시 간이후부터 유의하게 증가하였다 $(\mathrm{p}<0.05)$. $\mathrm{C} 18: 3$ 소실율은 $\mathrm{C} 18: 2$ 에 비해 사료에 의한 영 향을 받는 것으로 나타났고, 특히 기질 중 $\mathrm{C} 18: 3$ 함량과 밀접한 관계가 있는 것으로 사료 된다. Scollan 등 (2001a)의 연구에서도 $\mathrm{C} 18: 3$ 이 풍부한 아마종실과 아마종실/어유혼합구에서 biohydrogenation rate가 $94.3 \%$ 로 대조구인 $\operatorname{Megalac}^{\circledR}(88.8 \%)$ 보다 높게 나타나 본 실험과 유사한 결과를 나타내었으며, $\mathrm{C} 18: 3$ 의 소실율 이 배양 72 시간에서 두 처리구 평균 $95.01 \%$ 로 높은 소실율을 나타내었다. $\mathrm{C} 18$ 계 불포화지방 산 소실율은 $\mathrm{C} 18: 1, \mathrm{C} 18: 2, \mathrm{C} 18: 3$ 지방산의 총 합소실율 $(\%)$ 로서 $\mathrm{C} 18: 2$ 와 $\mathrm{C} 18: 3$ 소실율에 비 해 상대적으로 낮아졌으며, 이는 $\mathrm{C} 18: 1$ 지방산 소실율이 C18:1n-9 외에 여러 가지 이성질체의 생성으로 인한 과소평가로 기인되며, 아마종실 이 전지대두보다 유의하게 높은 소실율을 나타 내었다 $(\mathrm{p}<0.05)$. 


\section{IV. 요 약}

본 연구는 불포화지방산원으로서 $\mathrm{C} 18: 2 n-6$ 이 풍부한 전지대두와 $\mathrm{C} 18: 3 n-3$ 이 풍부한 아마종 실을 반추동물사료에 $18 \%$ 배합하였을 때 반추 위내 건물소실율과 불포화지방산 소실율 및 조 성을 조사하기 위해 in vitro 배양장치에서 실 시하였다. 배양시간은 $0,3,6,12,24,48,72$ 시 간에 걸쳐 실시하였고, 배양 종료 후 각각의 medium digesta는 동결 건조하여 건물과 각 지 방산 함량을 분석하였다. 배양 3 시간까지는 전 지대두와 아마종실의 건물소실율에 차이가 없 었으나, 배양 6시간이후부터는 아마종실이 전 지대두보다 유의한 증가를 나타내었다 ( $\mathrm{p}<$ 0.01). 하지만, 배양 48시간이후부터는 두 처리 구간에 유의차가 나타나지 않았다 $(\mathrm{p}>0.05)$. 한 편 가스생성량은 건물소실율과 비슷한 양상을 나타내어 아마종실이 전지 대두보다 발효산물인 가스를 보다 많이 생성하나 두 처리구간에 유 의한 차이는 나타나지 않았다( $\mathrm{p}>0.05) . \quad \mathrm{C} 18: 0$ 함량은 배양시간이 증가함에 따라 전지대두와 아마종실 공히 증가하였고, 전지대두가 아마종 실 보다 유의하게 높았다( $\mathrm{p}<0.05) . \mathrm{C} 18: 1$ 조성 은 전지대두가 아마종실구보다 유의하게 증가 하였다 $(\mathrm{p}<0.05) . \quad \mathrm{C} 18: 2$ 와 $\mathrm{C} 18: 3$ 의 digesta내 조 성은 반추위내 수소첨가현상으로 배양시간이 증가함에 따라 감소하였다. Digesta내 C18:2 함 량은 $\mathrm{C} 18: 2$ 가 풍부한 전지대두가 아마종실에 비하여 유의하게 증가하였고 $(\mathrm{p}<0.05), \mathrm{C} 18: 3$ 함 량은 $\mathrm{C} 18: 3$ 이 풍부한 아마종실이 전지대두에 비하여 유의하게 증가하였다 $(\mathrm{p}<0.001)$.

순수 $\mathrm{C} 18: 0$ 생산량 (\%)은 $\mathrm{C} 18: 2 n-6$ 함량이 풍부한 전지대두가 배양종료 후 $332.24 \%$ 로 아 마종실의 $133.16 \%$ 보다 유의하게 증가하였다 $(\mathrm{p}<0.05) . \mathrm{C} 18: 1$ 소실율은 전지대두가 아마종실 보다 유의하게 낮았고 $(\mathrm{p}<0.05)$, 특히 배양 3 , $6,12,24$ 시간에서 전지대두 처리구가 음 $(-)$ 값을 나타내었다. $\mathrm{C} 18: 2$ 의 소실율은 배양시간 이 증가함에 따라 증가하였고, 배양 72 시간에 두 처리구 평균 $93.31 \%$ 로 광범위하게 소실되었 으나, 처리구간 유의차는 나타나지 않았다 ( $>0.05) . \mathrm{C} 18: 3$ 소실율은 $\mathrm{C} 18: 2$ 소실율과 마찬
가지로 배양시간이 증가함에 따라 증가하였으 며, 특히 아마종실이 전지대두에 비하여 배양 6 시간이후부터 유의하게 증가하였다 $(\mathrm{p}<0.05)$. $\mathrm{C} 18$ 계 불포화지방산 소실율은 아마종실이 전 지대두보다 유의하게 높았다 $(\mathrm{p}<0.05)$. 이상의 결과로부터 전지대두와 아마종실은 반추동물의 식품 내 유익한 불포화지방산이 침착하는데 충 분한 가치가 있는 불포화지방산원이었고, $\mathrm{C} 18$ 계 불포화지방산은 반추위내에서 광범위하게 수소첨가되었다. 아울러 전지대두는 아마종실 보다 complete biohydrogenation이 증가하였고, digesta 내 불포화지방산 함량은 사료 중 불포 화지방산 함량과 밀접한 관계가 있었다.

\section{V. 인 용 문 헌}

1. AOAC. 1990. Official Methods of Analysis. 15th ed. Association of Official Analytical Chemists, Washington, DC.

2. Barlow, S. M., Young, F. V. K. and Duthie, I. F. 1990. Nutritional recommendations for $n-3$ polyunsaturated fatty acids and the challenge to food industry. Proceedings of the Nutrition Society. 49:13-21.

3. Broderick, G. A., Wallace, R. J., Ørskov, E. R. and Hansen, L. 1988. Comparison of estimates of ruminal protein degradation by in vitro and in situ methods. J. Anim. Sci. 66:1739-1745.

4. Choi, N. J., Enser, M., Wood, J. D. and Scollan, N. D. 2000. Effect of breed on the deposition in beef muscle and adipose tissue of dietary $n-3$ polyunsaturated fatty acids. Anim. Sci. 71:509-519.

5. Clinquart, A., Istasse, L., Dufrasne, I., Mayombo, A., van Eenaeme, C. and Bienfait, J. M. 1991. Effects on animal performance and fat composition of two fat concentrates in diets for growing-fattening bulls. Anim. Prod. 53:315-320.

6. Davies, D. R., Theodorou, M. K., Lawrence M. I. G. and Trinci, A. P. J. 1993. Distribution of anaerobic fungi in the digestive tract of cattle and their survival in faeces. J. Gen. Microbiol. 139: 1395-1400.

7. Dhiman, T. R., Anand, G. R., Satter, L. D. and Pariza, M. W. 1999. Conjugated linoleic acid 
content of milk from cows fed different diets. J. Dairy Sci. 82:2146-2156.

8. Doreau, M. and Ferlay, A. 1994. Digestion and utilization of fatty acids by ruminants. Anim. Feed Sci \& Technol. 45:379-396.

9. Elmeddah, Y., Doreau, M. and Michalet-Doreau. B. 1991. Interaction of lipid supply and carbohydrates in the diet of sheep with digestibility and ruminal digestion. J. Agric. Sci., 116: 437-445.

10. Enjalbert, F., Nicot, M. C., Vernay, M., Moncoulon, R. and Griess, D. 1994. Effect of different forms of polyunsaturated fatty acids on duodenal and serum fatty acid profiles in sheep. Can. J. Anim. Sci. 74:595-600.

11. Griinari, J. M., Dwyer, D. A., McGuire, M. A. and Bauman, D. E. 1996. Partially hydrogenated fatty acids and milk fat depression. J. Dairy Sci. 79 (suppl. 1):177 (abs.).

12. Harfoot, C. G. and Hazelwood, G. P. 1988. Lipid metabolism in the rumen. Pages 285-322 in The Rumen Microbial Ecosystem. P. N. Hobson, ed. Elsevier Applied Sci. Publishers, London.

13. Hogan, J. P., Connell, P. J. and Mills, S. C. 1972. The digestion of safflower oil casein particles protected against ruminal hydrogenation in sheep. Aust. J. Agric. Res. 23:87-95.

14. Ikwuegbu, O. A. and Sutton, J. D. 1982. The effect of varying the amount of linseed oil supplementation on rumen metabolism in sheep. Br. J. Nutr. 48:365-375.

15. Jenkins, T. C. 1993. Lipid metabolism in the rumen. J. Dairy Sci. 76:3851-3863.

16. Kelly, M. L., Kolver, E. S., Bauman, D. E., Van Amburgh, M. E. and Muller, L. D. 1998a. Effect of intake of pasture on concentrations of conjugated linoleic acid in milk of lactating cows. J. Dairy Sci. 81:1630-1636.

17. Kelly, M. L., Berry, J. R., Dwyer, D. A., Griinari, J. M., Chouinard, P. Y., Van Amburgh, M. E. and Bauman, D. E. 1998b. Dietary fatty acid sources affect conjugated linoleic acid concentrations in milk from lactating dairy cows. J. Nutr. 128:881-885.

18. Kucuk, O., Hess, B. W., Ludden, P. A. and Rule, D. C. 2001. Effect of forage:concentrate ratio on ruminal digestion and duodenal flow of fatty acids in ewes. J. Anim. Sci. 79:2233-2240.

19. Madron, M. S., Peterson, D. G., Dwyer, D. A., Corl, B. A., Baumgard, L. H., Beermann, D. H. and Bauman, D. E. 2002. Effect of extruded full-fat soybeans on conjugated linoleic acid content of intramuscular, intermuscular, and subcutaneous fat in beef steers. J. Anim. Sci. 80: 1135-1143.

20. McGuire, M. A., McGuire, M. K., Guy, M. A., Sanchez, W. K., Shultz, T. D., Harrison, L. Y., Bauman, D. E. and Griinari, J. M. 1996. Effect of dietary lipid concentration on content of conjugated linoleic acid (CLA) in milk from dairy cattle. J. Anim. Sci. 74 (suppl. 1):266 (abs.).

21. Mosley, E. E., Powell, G. L., Riley, M. B. and Jenkins, T. C. 2002. Microbial biohydrogenation of oleic acid to trans isomers in vitro. J. Lipid Res. 43:290-296.

22. NRC. 2001. Nutrient requirements of dairy cattle. 7th revised edition. National academy press, Washington, DC.

23. Palmquist, D. L. and Jenkins, T. C. 1980. Fat in lactation rations: review. J. Dairy Sci. 63:1-14.

24. Petit, H. V. 2002. Digestion, milk production, milk composition, and blood composition of dairy cows fed whole flaxseed. J. Dairy Sci. 85:14821490.

25. Sargent, J. R. and Henderson, R. J. 1995. Marine $(n-3)$ polyunsaturated fatty acids. In Developments in Oils and Fats (Ed. R. J. Hamilton), pp. 32-65. London: Blackies Academic and Professional.

26. SAS User's Guide:Statistics, release. 8.1 version Edition, 2000. SAS Inst., Inc. Cary, NC.

27. Scollan, N. D., Dhanoa, M. S., Choi, N. J., Maeng, W. J., Enser, M. and Wood, J. D. 2001a. Biohydrogenation and digestion of long chain fatty acids in steers fed on different sources of lipid. J. Agric. Sci. 136:345-355.

28. Scollan, N. D., Choi, N-J., Kurt, E., Fisher, A. V., Enser, M. and Wood, J. D. 2001b. Manipulating the fatty acid composition of muscle and adipose tissue in beef cattle. Br. J. Nutr. 85: 115-124.

29. Sukhija, P. S. and Palmquist, D. L. 1988. Rapid 
Lee et al.; In vitro Ruminal C18-unsaturated Fatty Acids Disappearances of Dietary Full-fat Soybeans and Linseed

method for determination of total fatty acid content and composition of feedstuffs and feces. J. Agric. Food Chem. 36:1202-1206.

30. Theodorou, M. K., Williams, B. A., Dhanoa, M. S., McAllan, A. B., France, J. 1994. A simple gas production method using a pressure transducer to determine the fermentation kinetics of ruminant feeds. Anim. feed Sci. \& Tech. 48:185-197.

31. Van Nevel, C. J. and Demeyer, D. I. 1996. Effect of $\mathrm{pH}$ on biohydrogenation of polyunsaturated fatty acids and their Ca-salts by rumen microorganisms in vitro. Arch. Anim. Nutr., 49:151157.

32. Wu, Z., Ohajuruka, O. A. and Palmquist, D. L. 1991. Ruminal synthesis, biohydrogenation, and digestibility of fatty acids by dairy cows. J. Dairy Sci. 74:3025-3034.

(접수일자 : 2003. 2. 3 / 채택일자 : 2003. 4. 7) 